\title{
THE PRESERVATION OF FRESH-WATER BRYOZOA
}

\author{
By F. Slater Jackson, M.D.
}

The following method is the outcome of a series of experiments made by the writer during the summer of 1916, while engaged in a preliminary study of the fauna of certain of the Laurentian lakes in Argenteuil County.

Attempts were made to preserve several species of Bryozoa in an expanded condition by treating specimens (previously narcotized with chloretone, cocain, chloral hydrate, etc.) with alcohols of grad ually increasing concentration, formalin and other reagents, but without success. Nor did the sudden killing and fixation of small colonies by means of well-known reagents, such as hot corrosive-acetic, chromacetic, osmic acid mixtures or Bouin's fluid, give better results.

For reasons afterwards to be discussed, the following method suggested itself to the writer, and has afforded good results for several species.

(1) Narcotization. Elongated colonies attached to twigs or to the stems of aquatic plants, are placed in water in a tube of convenient length, and of a diameter sufficient to permit of the colony lying obliquely, so that it may not come in contact with the tube except at the extremities. In the case of flattened forms, e.g., those occurring on leaves, etc., the operations are best conducted in Petri dishes. A saturated aqueous solution of cocain* is slowly added by means of a pipette. At first a small quantity of the solution (say 1 c.c.) is dropped upon the surface of the water and allowed to diffuse. A similar amount may be added at intervals of five minutes, a small quantity of the water being removed from time to time if necessary.

The retraction of the zooids caused by the first addition of the cocain is only temporary, and uniform expansion of the whole colony will be attained in about half an hour.

* A saturated aqueous solution of chloretone may be substituted, of which, how ever, a larger quantity will be required. 
When this stage is reached, about $5 \%$ of the entire fluid may be withdrawn, and replaced by the cocain solution, which is to be forcibly injected into the remaining fluid by means of the pipette, in order to ensure its uniform admixture.

After this time the colony should be observed at intervals with a lens, and if ciliary motion has ceased (as indicated by the cessation of vortices containing fæcal and other particles) no further addition of cocain is necessary.

Periodical stimulation (either by touching the individual extended lophophores with a needle, or, preferably, by setting up currents with the pipette) will indicate the degree of narcotization. This will probably be complete in from one to one and a half hours, but will vary with the species.

In every case it will be advisable to wait for ten minutes after there is no further response to stimuli, before adding the preserving fluid, otherwise immediate and permanent retraction may follow its addition.

(2) Preservation. The tube or dish containing the narcotized colony is placed in a convenient vessel (to permit of overflow) and the narcotizing fluid gradually replaced by a fluid having the following composition:-

$\begin{array}{lr}\text { Cane sugar } & 10 \text { parts } \\ \text { Formalin } & 2 \text { parts } \\ \text { Distilled water to } & 100 \text { parts }\end{array}$

(The sugar is to be dissolved in the water and the formalin subsequently added.)

The replacement is made by injecting the preserving fluid (a pipetteful at a time) with sufficient force to ensure its admixture with the narcotizing fluid, and its uniform contact with the colony. When it is estimated that the fluid consists of approximately $50 \%$ of the sugar solution, the preparation may be allowed to remain in this for about half an hour. At the expiration of that time the preserving fluid may be added more rapidly until it almost completely replaces the former mixture. The colony is then left undisturbed for half an hour or more, and may then be transferred to a fresh vessel containing the undiluted preserving fluid.

The time required for the entire process, from the commencement of narcotization, is about $2 \frac{1}{2}$ hours, but will be found to vary slightly for different species. 
Numerous preparations of Plumatella, Fredericella and Cristatella, made according to this method in August, 1916 are still in an excellent state of preservation.

It is suggested that the fluid be changed after the lapse of a week or ten days.

While not primarily designed as a microscopic or histological method, the above treatment has been found to afford an adequate means of preliminary preservation for material to be subsequently employed in the preparation of slides, or even of sections.

For this purpose individual zooids or small portions of the colony are to be dropped into Bouin's fluid, ${ }^{*}$ allowed to remain in this for a few hours, and then transferred to $70 \%$ alcohol.

When free from picric acid they may be stained in toto and mounted, or embedded in paraffin in the usual way.

It has been found that the tissues, and even the cilia, are well preserved.

The formalin-sugar solution has, with modifications, been successfully employed for the preservation of insect larvæ and pupæ,$^{1}$ and may also be used for various small invertebrates.

A consideration of some aspects of the question of the permeability of cell-membranes, and of the adsorption phenomena of cane sugar, suggested the possibility of the application of a solution such as the above in the preservation of Bryozoa. Since the surface tension at the interface between water and other phases is but slightly reduced by sugar, and, as has been pointed out by Michaelis and Roona, ${ }^{2}$ and by Parkin, ${ }^{3}$ adsorption of sugar does take place at such surfaces, the employment of a sugar solution offers possibilities for the preservation of delicate tissues. The observations of $\mathrm{Küster}^{4}$ on the cells of the onion, plasmolyzed by hypertonic sugar solution, seem to indicate that there is a certain degree of fixation of the surface membrane.

Furthermore in view of the fact that, as established by Freundlich, ${ }^{5}$ gelatin will adsorb sugar only after preliminary treatment with formalin, and since the experiments of Lloyd ${ }^{6}$ have indicated the essential similarity of protoplasm and gelatin as regards their behavior in imbibition and similar phenomena, it was thought that the

$\begin{array}{lr}\text { *Picric acid, saturated aqueous solution } \ldots \ldots \ldots . . . & 75 \\ \text { Formalin } & \\ \text { Glacial acetic acid } & \end{array}$


employment of sugar and formalin in combination might provide an efficient preservative for these organisms.

It is suggested that the efficacy of the method is due to the fixation of the protoplasm by the formalin, and to the protective action of the adsorbed sugar.

The employment of formalin alone as a preservative, although recommended by Green ${ }^{7}$ and by Davenport ${ }^{8}$ has, in the writer's hands, invariably proved fatal.

As is well known, formalin combines chemically with proteins, and in the case of fresh-water Bryozoa, it results in the formation of a flocculent precipitate, and the ultimate separation and disintegration of the lophophores. Similarly, while one of the best preservatives for marine Cœlenterates, it gives poor results with Hydra. On the other hand, it proves excellent for the free-swimming larvæ of Bryozoa, and for statoblasts.

Zoological Laboratory, McGill University,

June 10th, 1919.

\section{LITERATURE CITED}

JACKSON, F. SLATER

(1) 1919. "A method for the preservation of Insect Larvae and Pupae." Can. Entomologist. Vol. 51, No. 5. May 1919, pp. 117-118.

Michaelis, L. and Roona P.

(2) 1909. "Adsorption des Zuckers" Bioch. Zs. Bd. 16, pp. 489-498.

PARKIN, J.

(3) 1911. "Carbohydrates of the Foliage Leaf of the Snowdrop." Bioch. Jl., Vol. 6, pp. 1-47.

KüSTER, E.

(4) 1909. "Ueber die Verschmelzung nacter Protoplasten" Ber. Deutsch. Bot. Ges., Bd. 27, pp. 589-598.

FREUNDLICH, H.

(5) 1909. "Kapillarchemie."

LLOYd, Francis, E.

(6) 1917. "The Colloidal properties of Protoplasm: Imbibition in relation to growth" Trans. Royal Soc. Canada, Sect. 4, 1917, p. 139.

Green, Bessie R.

(7) 1914. "Preservation of Bryozoa" Trans. Amer. Micros. Soc. Vol. 33, No. 1, Jan. 1914, pp. 55-56.

Davenport, C. B.

(8) 1918. (in Ward and Whipple's "Fresh-water Biology," p. 951.

For the accompanying photographs, I am indebted to Mr. W. B. Stokes, Secretary of the Montreal Natural History Society. Plate XXI is Cristatella mucedo and Plate XXII is Fredericella sp. 


\section{$2 \mathrm{BHL}$ Biodiversity Heritage Library}

Jackson, F Slater. 1919. "The Preservation of Fresh-Water Bryozoa." Transactions 38, 217-220.

View This Item Online: https://www.biodiversitylibrary.org/item/84904

Permalink: https://www.biodiversitylibrary.org/partpdf/90859

\section{Holding Institution}

University of Toronto - Gerstein Science Information Centre

\section{Sponsored by}

University of Toronto

\section{Copyright \& Reuse}

Copyright Status: Not provided. Contact Holding Institution to verify copyright status.

This document was created from content at the Biodiversity Heritage Library, the world's largest open access digital library for biodiversity literature and archives. Visit BHL at https://www.biodiversitylibrary.org. 